\title{
Influence of Air Humidity Variation on Strength of Rotary Welded Dowel Joints of Pinewood
}

\section{Utjecaj promjene vlažnosti zraka na čvrstoću kružno zavarenih spojnih elemenata od borovine}

\author{
Preliminary paper • Prethodno priopćenje \\ Received-prispjelo: 26. 9. 2018. \\ Accepted-prihvaćeno: 4. 7. 2019. \\ UDK: $630 * 824.131 ; 630 * 824.521$ \\ https://doi.org/10.5552/drvind.2019.1846
}

\begin{abstract}
A rotary welded joint is a combination of wood in which chemical and physical reactions occur due to friction. During the welding process, heat is generated which softens and melts the wood structure. In this way, interlocked wood fibres in the lignin melt are created within the joint. As the welded joint cools down, it becomes a tight weld. The paper describes the research based on studying the impact of individual factors on the welded joint. Outcome variables are the average ring width, the water content in the wood, and the influence of different humidity levels on the strength of rotary welds. Samples were subjected to the influence of different humidity levels achieved by air conditioning, magnesium chloride and sodium chloride. Absolutely dry samples exhibited the lowest embedded force values (the average embedded force value for heartwood amounted to $1901 \mathrm{~N}$ and for sapwood $1920.36 \mathrm{~N}$ ), while the air conditioned samples (the average embedded force value amounted to 2649.06 $\mathrm{N}$; for sapwood 2679.6 $\mathrm{N}$ and for heartwood $2619.6 \mathrm{~N}$ ). The samples exposed to sodium chloride (the average embedded force value amounted to $2907.7 \mathrm{~N}$; for sapwood $2766.07 \mathrm{~N}$ and for heartwood $3049.33 \mathrm{~N}$ ) exhibited the highest embedded force values. This paper presents a descriptive statistical analysis of the strength of rotary welded dowels in the pine base. The aim of the study was to research the influence of different air humidity levels on the embedded force of Scots pine rotary welds. As the air relative humidity and temperature change during the daily application of the product (which affects the moisture content in the wood), the knowledge on the influence that humidity and water content in the wood exert on the welded joint strength turns out to be of great importance for its use.
\end{abstract}

Keywords: welding solid wood, Scots pine (Pinus sylvestris L.), dowels, strength of welded joints, weld factors, embedded force, the impact of humidity on wood, wood moisture content

SAŽETAK • Kružno zavareni spoj jest spoj drva u kojemu se zbivaju kemijsko-fizikalne reakcije pod utjecajem trenja. Tijekom procesa zavarivanja stvara se toplina, zbog koje struktura drva omekša i rastali se, pa se te drvna vlakanca u talini lignina međusobno isprepletu. Pri hlađenju zavarenog spoja nastaje čvrsto zavareni spoj. U radu je opisano istraživanje utjecaja pojedinih čimbenika na zavareni spoj, u sklopu kojega su promatrani sadržaj vode u drvu te utjecaj različite vlažnosti zraka na čvrstoću kružno zavarenih spojeva. Uzorci su izlagani zraku različite vlažnosti, što je postignuto njihovim kondicioniranjem te solima magnezijeva i natrijeva klorida. Apsolutno suhi

\footnotetext{
Authors are researcher, professor and associate professor at University of Zagreb, Faculty of Forestry, Zagreb, Croatia.

Autori su istraživač, profesor i izvanredni profesor Sveučilišta u Zagrebu, Šumarski fakultet, Zagreb, Hrvatska.
} 
uzorci pokazali su najniže vrijednosti izvlačne sile (prosječna vrijednost te sile za srž iznosila je 1901 N, a za bjeljiku 1920,36 N), a zatim slijede klimatizirani uzorci (prosječna vrijednost izvlačne sile iznosila je 2649,06 N; za bjeljiku 2679,6 N, a za srž 2619,6 N). Uzorci izloženi natrijevu kloridu pokazali su najviše vrijednosti izvlačne sile (njezina prosječna vrijednost iznosila je 2907,7 N; za bjeljiku 2766,07 N, a za srž 3049,33 N). U radu je prikazana deskriptivna statistička analiza čvrstoće moždanika kružno zavarenih u borovinu. Sobzirom na to da se pri svakodnevnoj uporabi proizvoda mijenja relativna vlažnost zraka i temperatura (što utječe na promjene sadržaja vode u drvu), poznavanje utjecaja vlažnosti zraka i sadržaja vode u drvu na čvrstoću zavarenog spoja vrlo je važno za пјеgovu primjenu.

Ključne riječi: zavarivanje masivnog drva, borovina (Pinus sylvestris L.), moždanik, čvrstoća zavarenog spoja, čimbenici zavarivanja, izvlačna sila, utjecaj vlažnoga zraka na drvo, sadržaj vode u drvu

\section{INTRODUCTION} 1. UVOD

Humankind is showing an increasing environmental awareness and social responsibility nowadays so that the demand for environmentally friendly products is increasing as well. The application of welded wood joints may play a major role in the production and use of wood products. Welded joints not only achieve approximately the same embedded force values as glued joints, but they are also ecologically friendly as only natural materials are used for welding. During their recycling or incineration, such joints do not release toxins and they behave as natural wood. (Stamm et al., 2005).

Wood welding is done by heat and pressure (rotation and vibration) generated between one or more elements. The advantage of this procedure is that no adhesive is needed and, as such, it is the most environmentally benign. During the welding process, the components (lignin and hemicelluloses) soften thermally, which leads to polymerization, while surface wood layers melt when in contact (due to friction between materials). As a result, the cell wall in the interfacial zone is destroyed and the density in the welding zone increases considerably. Mechanical friction (which produces high temperatures), pressure forces and chemical reactions at the cooling stage make cell walls burst. The joints produced in this way can be compared to other ways of bonding. Chemical changes resulting from welding have not been included in this research. Instead, already known facts from available literature have been used. Much recent research has been dedicated to wood to find new ways of application of this valuable and renewable raw material (Župčić, 2010).

During the rotation in wood welding, the dowel surface and volume decrease, while the welding hole increases. The wood density in the welding zone increases considerably because of the total destruction of cells. Wood welding is determined by the temperature, melting of certain amorphous polymeric substances and by mutual bonding of wood tissue in the wood structure. Certain studies showed that the welded joint could be much stronger than the glued joint (Župčić, 2010).

This paper presents the descriptive statistical analysis of the strength of a rotary welded dowel that was exposed to different humidity levels. The aim was to research the influence of different humidity levels on the strength of welded joints with regard to the fact that relative humidity and temperature change during the application of the product, which affects the water content in the wood. The knowledge of the influence that relative air humidity has on the welded joint strength turns out to be important for the future application in manufacture and for everyday use.

The research is based on studying the impact of individual factors on the welded joint. The factors that were observed include the water content in the wood and impact of different humidity levels on the strength of rotary welded joints. Eighty samples were used for the research. Three holes were drilled on each sample into which dowels were welded. After the selection of 80 samples, they were divided into two groups consisting of 40 samples from the sapwood zone, and 40 samples from the heartwood zone. The samples divided in this way were exposed to different air humidity levels. One group consisted of samples that were absolutely dry, the other group of air-conditioned samples and the remaining two of samples exposed to different of air humidity (obtained by magnesium chloride and sodium chloride).

Pizzi et al. (2006) researched the influence of water on the welded joint. A grooved beech dowel having $10 \mathrm{~mm}$ in diameter was welded to a beech base $(30 \mathrm{~mm}$ $\times 30 \mathrm{~mm} \times 30 \mathrm{~mm}$ ) in an $8 \mathrm{~mm}$ hole. The welding depth was $20 \mathrm{~mm}$, the rotation frequency 1515 revolution $/ \mathrm{min}$, and the weld time was $3 \mathrm{~s}$. The control samples were glued using PVAc adhesive and conditioned over $24 \mathrm{~h}$. The samples were immersed in cold water over a period of 24 hours. The research results show that the embedded force of the treated samples amounted to $88 \%$ of the embedded force of the untreated samples.

Jones and Pizzi (2007) studied the influence of cold and boiling water on the strength of the welded joint of modified Sitka spruce wood. The results show a greater embedded force of the joints of thermally and chemically (alcohol based) modified wood during a 2-hour period of exposure to boiling water. The unmodified samples exhibited the greatest embedded force under normal conditions, whereas the chemically modified samples (modified by an acetylation agent) exhibited the greatest embedded force when exposed to cold water. It was demonstrated that the technique of modified wood welding is applicable, and that it improves the joint strength when exposing the welded joints to the influence of humidity and moisture. The research results show that the use of modified wood for welding can produce a joint that is more resistant to humidity. This opens up new opportunities for the application of the wood welding technique. 
Leban et al. (2008) studied the impact of frequency on rotational welding. They used grooved beech dowels (Fagus Sylvatica) of $12 \mathrm{~mm}$ in diameter and $80 \mathrm{~mm}$ in length. The samples were made of spruce wood (Picea Abies) with a water content of $12 \%$. Receiver holes had a diameter of $9.5 \mathrm{~mm}$ to a depth of 15 $\mathrm{mm}$, and of $8 \mathrm{~mm}$ to a depth of $46 \mathrm{~mm}$. Embedded strength was examined on the samples that were welded at the frequencies of 1500, 4000, 6000 and 6500 $\min ^{-1}$. Welding time was between 2 and $4 \mathrm{~s}$. The best results in embedded strength were obtained at a frequency of $1500 \mathrm{~min}^{-1}$, whereas an increase in frequency resulted in lower strength. Higher welding frequencies produced a higher concentration of destroyed tissue i.e. a high increase in temperature was generated, so that melted material shifted further away from the bond line and thus created a gap.

Župčić et al. (2014) examined the impact of wood species such as beech, oak and spruce on the welded joint strength by examining the embedded strength (parallel and perpendicular to the fibres) and the impact of the ring width on the joint strength. Altogether 365 samples were made, out of which 359 were used for further research (bursting occurred in six samples). There were 16 different sample types with the dimensions of 200 $\mathrm{mm} \times 30 \mathrm{~mm} \times 30 \mathrm{~mm}$ with 30 sample pieces of each type. For each sample, grooved dowels were welded into drilled holes of $8 \mathrm{~mm}$ in diameter in the radial, radial-tangential and tangential direction. The sample type, where the hole was drilled in the same direction as the fibre orientation, had the dimensions of $30 \mathrm{~mm} \times 30 \mathrm{~mm}$ $\times 64 \mathrm{~mm}$, and when the sample was cut to be examined under the magnifying glass, its dimensions were of 30 $\mathrm{mm} \times 30 \mathrm{~mm} \times 30 \mathrm{~mm}$. The average dowel was 10.04 $\mathrm{mm}$ in diameter and the weld penetration amounted to $20 \mathrm{~mm}$. The rotation frequency was $1520 \mathrm{~min}^{-1}$ and the average tightness after the welding was $2.09 \mathrm{~mm}$. A computer for measuring force and displacement was used for testing the embedded strength on the universal testing machine so that values were determined with a 5 $\mathrm{N}$ certainty. The testing was carried out with a $5 \mathrm{~mm} / \mathrm{min}$ displacement. The results showed that there is a significant difference between the dowels welded parallel and perpendicular to the fibre orientation. The beech samples, with the dowels welded in the same direction as the fibre orientation, showed the best embedded strength values. The spruce samples, with the dowels welded in the same direction as the fibre orientation, showed the lowest embedded force values. In case of the dowels welded perpendicular in the radial, radial-tangential and tangential direction no statistically significant difference was recorded.

\section{MATERIALS AND METHODS}

\section{MATERIJALI I METODE}

\subsection{Solid wood selection}

\subsection{Izbor masivnog drva}

Scots pine (Pinus sylvestris L.) was used for the research. The material was selected randomly from the stack of sawn dry timber. The only selection criterion was that the sawn timber be of regular structure, without any knots, cracks and damages. Scots pine belongs to conifers. Conifer tissue between wood rays consists exclusively or mostly of tracheids arranged in regular radial sequences. Such wood structure is suitable for evenly distributed stress along the joint and, therefore, for the preparation and processing of welding samples of good quality. Materials required for the testing were taken from the commercial stack so that possible changes during the testing could be linked to wood elements from the standard manufacture. Results obtained in this way could reveal joint properties that could be applied later under real conditions.

\subsection{Preparation of samples for welding} perpendicular to fibre orientation

2.2. Priprema uzoraka za zavarivanje okomito na smjer vlakanaca

\subsubsection{Determination of initial moisture content in samples}

2.2.1. Određivanje početnog sadržaja vode u uzorcima

The initial moisture content was determined by the gravitational method according to HRN ISO 130611:2015 by Eq. 1:

$$
W=\frac{m_{W}-m_{2}}{m_{2}} \cdot 100
$$

where $W$ is the moisture content in the wood after 7 days according to HRN ISO 13061-1:2015 (\%), $m_{W}$ is the initial probe mass $(\mathrm{g})$ and $m_{2}$ is the probe mass after 7 days $(\mathrm{g})$.

Wood density was determined on the same samples according to HRN ISO 13061-2:2015 by Eq. 2:

$$
\rho=\frac{m}{V}
$$

where $\rho$ is wood density $\left(\mathrm{g} / \mathrm{cm}^{3}\right), m=$ mass $(\mathrm{g})$ and $V$ $=$ volume $\left(\mathrm{cm}^{3}\right)$.

\subsubsection{Preparation of Scots pine specimens \\ 2.2.2. Priprema uzoraka borovine}

At the beginning of the samples preparation, specimens were taken to determine the initial moisture content and wood density (pinewood). Specimens were divided into two sample groups, 12 heartwood specimens and 12 sapwood specimens, which were used to determine the initial moisture content. Specimen dimensions and masses were measured to determine the specimen moisture content and density by the gravimetric method. The average moisture content in sapwood specimens amounted to $10.25 \%$ (the minimum moisture content was 9.71 and maximum $12.37 \%$ ), while the average density amounted to $0.498 \mathrm{~g} / \mathrm{cm}^{3}$ (the minimum density was $0.488 \mathrm{~g} / \mathrm{cm}^{3}$ and maximum $0.511 \mathrm{~g} / \mathrm{cm}^{3}$ ). The average moisture content in heartwood samples amounted to $9.78 \%$ (the minimum moisture content was $9.21 \%$ and maximum $11.99 \%$ ), while the average density amounted to $0.560 \mathrm{~g} / \mathrm{cm}^{3}$ (the minimum density was $0.549 \mathrm{~g} / \mathrm{cm}^{3}$ and maximum $\left.0.569 \mathrm{~g} / \mathrm{cm}^{3}\right)$.

During their preparation all specimens were sawn, planed and cut down to their final dimensions, and receiver holes were drilled. Specimens with dimensions of $30 \mathrm{~mm} \times 200 \mathrm{~mm} \times 30 \mathrm{~mm}$ were used for the research. Sawn and planed laths with the dimen- 


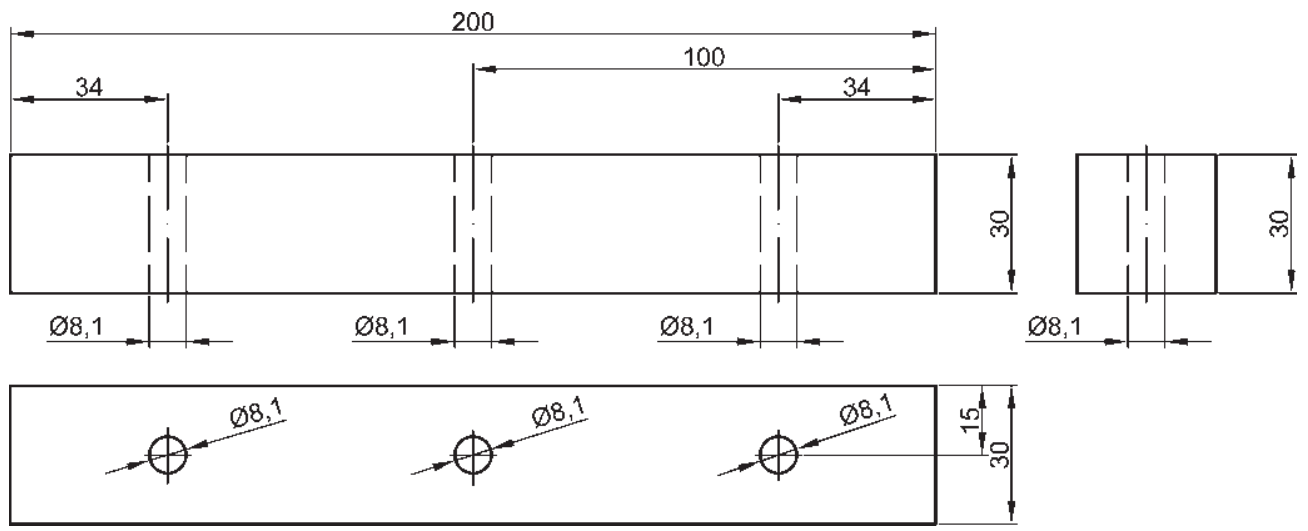

Figure 1 Testing sample for dowel welding

Slika 1. Ispitni uzorak pripremljen za zavarivanje moždanika

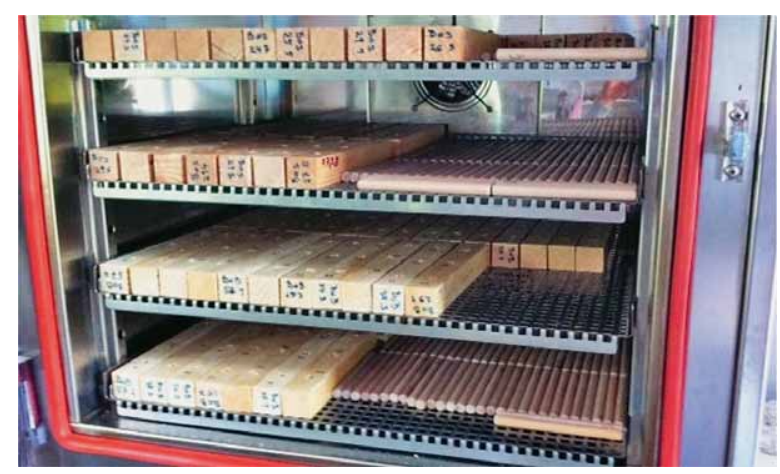

Figure 2 Specimens prepared for drying

Slika 2. Uzorci pripremljeni za sušenje

sions of cross section of $30 \mathrm{~mm} \times 30 \mathrm{~mm}$ were cut to the length of $200 \mathrm{~mm}$ by transversal sawing. After transversal sawing of the sample laths, specimens were divided into 40 specimens from the sapwood zone and 40 specimens from the heartwood zone. All specimens were of radial-tangential texture.

Three receiver holes were drilled in each specimen. The distance between the hole and the sample ends was $34 \mathrm{~mm}$, while the middle hole was made $100 \mathrm{~mm}$ from the sample end. The holes had a diameter of 8.1 $\mathrm{mm}$ and the welding direction was radial-tangential. Figure 1 shows the sample with drilled holes of $8.1 \mathrm{~mm}$.

The sample holes were drilled by means of a tightly fixed drilling machine on the working desk at the rotation frequency of $1520 \mathrm{~min}^{-1}$ with the spiral steel drilling bit of $8.1 \mathrm{~mm}$ in diameter and HSS mark. The prepared samples were weighed on a digital weighing scale with the reading possibility of $0.0001 \mathrm{~g}$

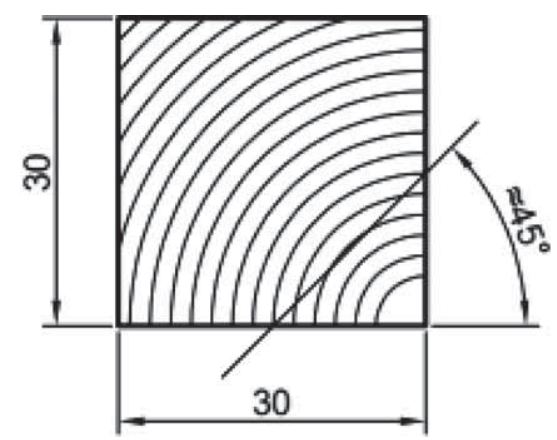

Figure 3 Manner of determining the ring width Slika 3. Način određivanja širine goda and then dried in an oven at the temperature of $(103 \pm 2)$ ${ }^{\circ} \mathrm{C}$ and $0 \%$ moisture content (Figure 2).

Besides the density and the average water content, the average ring width was determined as well by counting rings along the $30 \mathrm{~mm}$ width. The average ring width was measured by dividing the width of 30 $\mathrm{mm}$ (radial direction) by the number of rings on that width (Figure 3 ). The average ring width on heartwood samples amounted to $1.74 \mathrm{~mm}$ and on sapwood samples to $1.98 \mathrm{~mm}$.

\subsubsection{Dowel preparation}

\subsubsection{Priprema moždanika}

Dowels were needed for the testing. They were obtained from smooth wooden sticks of $1000 \mathrm{~mm}$ in length and $10 \mathrm{~mm}$ in diameter and they were sawn to the length of $120 \mathrm{~mm}$. Subsequently, their ends were bevelled by $1 \mathrm{~mm}$ at the angle of $45^{\circ}$.

Dowel bevelling was necessary for easier welding of the samples. After the processing, the dowels were weighed on the digital weighing scale with the reading possibility of $0.0001 \mathrm{~g}$ and put in the oven together with the samples at the temperature of $(103 \pm$ $2{ }^{\circ} \mathrm{C}$. The average moisture content and density were obtained by the gravimetric method. The average moisture content of the dowels amounted to $9.57 \%$ according to HRN ISO 13061-1:2015 and the dowel density to $0.662 \mathrm{~g} / \mathrm{cm}^{3}$ according to HRN ISO 130612:2015.

\subsection{Dowel rotary welding in prepared specimens}

2.3. Kružno zavarivanje moždanika u pripremljene uzorke

After drying in the oven at $(103 \pm 2){ }^{\circ} \mathrm{C}$, the specimens and dowels were weighed on a digital scale. The weighed specimens and dowels were put into plastic boxes to keep their moisture content constant during their transport to the room for dowel welding. The dowel rotary welding in specimens was performed in a room with the temperature of $22{ }^{\circ} \mathrm{C}$ and the relative humidity of $58 \%$.

The sample welding was carried out by an adapted device with the possibility of dowel rotation. The welding was performed by rotating the dowel at the rotation frequency of $1520 \mathrm{~min}^{-1}$ during the welding. The time needed to weld the dowel into the specimen 


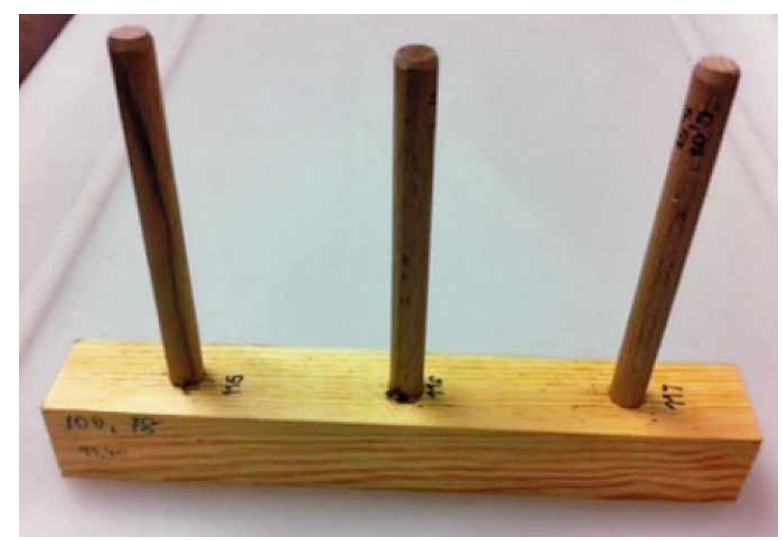

Figure 4 Testing specimens prepared for testing

Slika 4. Uzorci pripremljeni za ispitivanje

was $1.4 \mathrm{~s}$, while the pressure on the dowel after the welding was applied for 3 to 5 seconds. The weld penetration amounted to $20 \mathrm{~mm}$. The specimen, into which the dowels were welded, was immovable (static). Figure 4 shows the testing specimen prepared for embedded force testing.

After 80 samples had been welded, the probes were divided into four groups. Within each group there were 10 samples of sapwood and 10 samples of heartwood (three holes were drilled on each sample, each group with 60 welded dowels, 30 on heartwood samples and 30 on sapwood samples). One of the four sample groups (10 samples of sapwood and 10 samples of heartwood) was tested on the universal testing machine immediately.

The other sample group was conditioned under the laboratory conditions for a month at the temperature of $(23 \pm 2){ }^{\circ} \mathrm{C}$ and the relative humidity of $(50 \pm 5)$ $\%$. After exposing the samples to climatic conditions for a month, the samples were transferred to the room equipped with the universal testing machine at the Department for Wood Science. Immediately after the testing, the water content was measured by the gravimetric method. The average water content after the exposure to climatic conditions amounted to $10.05 \%$.

The third sample group was exposed to magnesium chloride $\left(\mathrm{MgCl}_{2}\right)$ and the fourth to sodium chlo-

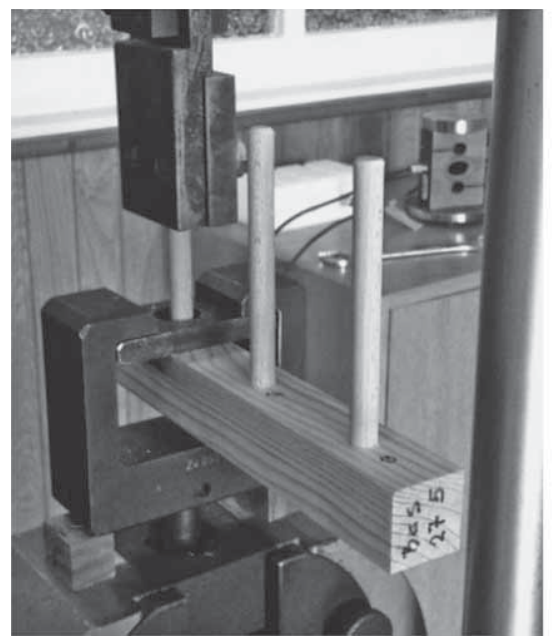

ride $(\mathrm{NaCl})$. The magnesium and sodium chloride salts were dissolved in water until the mixture turned into mesh. After the mixture has been prepared, metal stands were put in plastic boxes in which samples were placed. The boxes with closed samples were left for four weeks ( 25 days). After removing the samples from the boxes, the water content was determined.

The average water content for the samples exposed to sodium chloride $(\mathrm{NaCl})$ amounted to $13.05 \%$ (the average water content for heartwood samples was $12.41 \%$ and for sapwood samples $13.70 \%$ ). The average water content for the samples exposed to magnesium chloride $\left(\mathrm{MgCl}_{2}\right)$ amounted to $8.87 \%$ (the average water content for heartwood samples was $8.71 \%$ and for sapwood samples $9.03 \%$ ).

\subsection{Embedded force testing \\ 2.4. Ispitivanje izvlačne sile}

The testing was carried out on the universal testing machine. Due to the specific nature of the testing, a new part for the universal testing machine was made for catching dowels to avoid their slipping out so that the testing could be carried out smoothly (Figure 5). The universal testing machine adapted in this way allows the centreline axis of the sample to be parallel with the centreline axis of the universal testing machine on which the force acts. The displacement on the universal testing machine during the testing was 5 $\mathrm{mm} / \mathrm{min}$

\section{RESULTS AND DISCUSSION}

\section{REZULTATI I RASPRAVA}

Properties of the welded joint were determined by measuring the embedded force of the dowel from the sample. All research results were processed in $\mathrm{Mi}$ crosoft Excel 13 and Statistica 12 programs and the embedded force results were compared accordingly after the testing (Table 1). Figure 6 shows the comparison of embedded forces for all sample groups. It may be concluded that there is no significant statistical difference $(p<0.001)$ between embedded force values of the conditioned samples (heartwood and sapwood), the

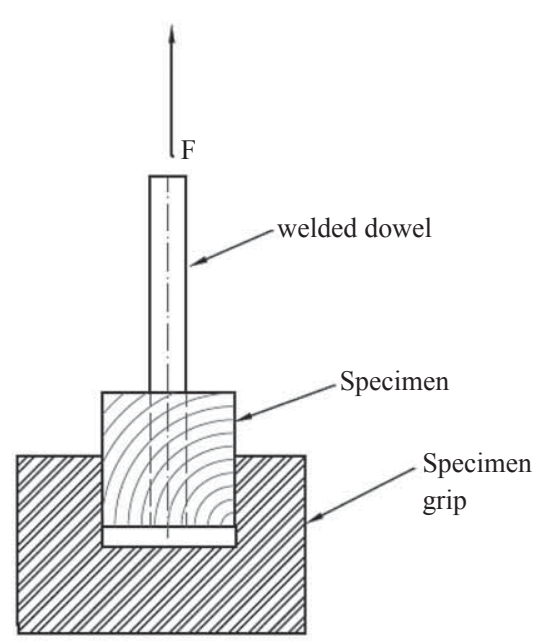

Figure 5 Manner of placing the testing specimen in the universal testing machine

Slika 5. Način postavljanja ispitnih uzoraka u univerzalni stroj za ispitivanje 
Žulj, Grbac, Župčić: Influence of Air Humidity Variation on Strength of Rotary Welded... .....

Table 1 Descriptive statistics of embedded force for all groups of specimens

Tablica 1. Deskriptivna statistika izvlačne sile za sve skupine uzoraka

\begin{tabular}{|c|c|c|c|c|c|c|c|c|c|}
\hline \multirow[b]{2}{*}{$\begin{array}{l}\text { Sample code } \\
\text { Oznaka uzorka }\end{array}$} & \multirow[b]{2}{*}{$\begin{array}{c}\text { MC in } \\
\text { specimens, } \\
\% \\
\text { Sadržaj } \\
\text { vode u } \\
\text { uzorcima, \% }\end{array}$} & \multirow[b]{2}{*}{$\begin{array}{c}\text { Number } \\
\text { of } \\
\text { speci- } \\
\text { mens } \\
\text { Broj } \\
\text { uzoraka }\end{array}$} & \multicolumn{7}{|c|}{ Embedded force / Izvlačna sila } \\
\hline & & & $\begin{array}{l}\text { Means, } \\
\mathbf{N} \\
\text { Srednja } \\
\text { vrijed- } \\
\text { nost, } N\end{array}$ & $\begin{array}{c}\text { Standard } \\
\text { deviation, } \mathbf{N} \\
\text { Standardna } \\
\text { devijacija, } \mathrm{N}\end{array}$ & $\underset{\mathbf{N}}{\operatorname{Min}}$ & $\underset{\mathbf{N}}{\operatorname{Max}}$ & $\begin{array}{c}\text { Q25, } \\
\text { N }\end{array}$ & $\begin{array}{c}\text { Median, } \\
\mathbf{N}\end{array}$ & $\begin{array}{l}\text { Q75, } \\
\text { N }\end{array}$ \\
\hline $\begin{array}{l}\text { 1. Oven dry (heartwood) } \\
\text { 1. osušeno (srž) }\end{array}$ & 0.0 & 30 & 1900.7 & 305.3 & 1335 & 2455 & 1622 & 1953,5 & 2185 \\
\hline $\begin{array}{l}\text { 2. Oven dry (sapwood) } \\
\text { 2. osušeno (bjeljika) }\end{array}$ & 0.0 & 30 & 1920.3 & 394.8 & 1155 & 2840 & 1670 & 1832,5 & 2110 \\
\hline $\begin{array}{l}\text { 3. Magnesium Chloride } \\
\text { (heartwood) } \\
\text { 3. magnezijev klorid (srž) }\end{array}$ & 8.71 & 30 & 2901.1 & 300.0 & 2250 & 3510 & 2650 & 2935 & 3100 \\
\hline $\begin{array}{l}\text { 4. Magnesium Chloride } \\
\text { (sapwood) } \\
\text { 4. magnezijev klorid (bjeljika) }\end{array}$ & 9.03 & 24 & 2948.9 & 488.9 & 2130 & 4000 & 2620 & 2912,5 & 3237,5 \\
\hline $\begin{array}{l}\text { 5. Conditioned samples } \\
\text { (heartwood) } \\
\text { 5. kondicionirani uzorci (srž) }\end{array}$ & 10.05 & 30 & 2619.6 & 240.1 & 2270 & 3190 & 2420 & 2610 & 2810 \\
\hline $\begin{array}{l}\text { 6. Conditioned samples } \\
\text { (sapwood) } \\
\text { 6. kondicionirani uzorci (bjeljika) }\end{array}$ & 10.05 & 30 & 2679.6 & 588.4 & 1320 & 4080 & 2340 & 2625 & 3150 \\
\hline $\begin{array}{l}\text { 7. Sodium chloride (heartwood) } \\
\text { 7. natrijev klorid (srž) }\end{array}$ & 12.41 & 30 & 3049.3 & 514.4 & 1950 & 4050 & 2675 & 3045 & 3440 \\
\hline $\begin{array}{l}\text { 8. Sodium chloride (sapwood) } \\
\text { 8. natrijev klorid (bjeljika) }\end{array}$ & 13.70 & 28 & 2766.0 & 548.0 & 1785 & 4095 & 2295 & 2710 & 3147,5 \\
\hline All groups / sve skupine & & 232 & 2587.7 & 603.0 & 1155 & 4095 & 2207 & 2620 & 3000 \\
\hline
\end{tabular}

samples exposed to magnesium chloride (heartwood and sapwood) and the samples exposed to sodium chloride (sapwood).

The statistical analysis showed no statistically significant difference between embedded forces for absolutely dry samples (heartwood and sapwood). Namely, absolutely dry samples exhibited the lowest embedded force values (the average embedded force value for heartwood amounted to $1901 \mathrm{~N}$ and for sapwood to $1920.36 \mathrm{~N}$ ), while the air conditioned sam-

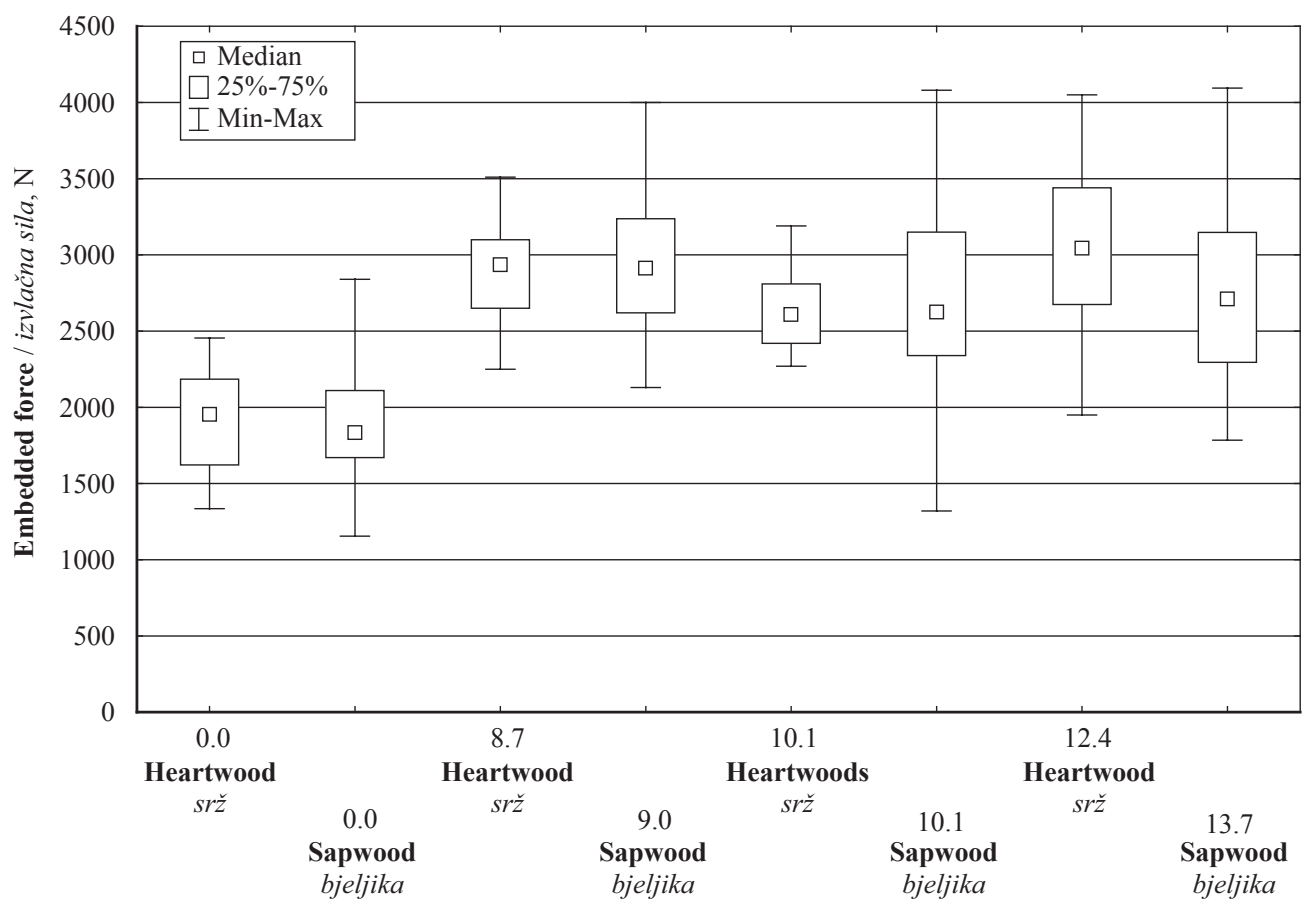

Samples moisture content / sadržaj vode uzoraka, \%

Figure 6 Comparison of embedded forces between groups of specimens conditioned to different MC

Slika 6. Usporedba izvlačne sila uzoraka kondicioniranih na različit sadržaj vode 
ples (the average embedded force value amounted to 2649.06 N; for sapwood 2679.6 N and for heartwood $2619.6 \mathrm{~N})$, and the samples exposed to sodium chloride (the average embedded force value amounted to 2907.7 N; for sapwood 2766.07 N and for heartwood $3049.33 \mathrm{~N}$ ) exhibited the highest embedded force values.

A comparison between the results obtained by the statistical analysis of the embedded force values and the water content in the wood, and the statistical analysis of the embedded force values of the samples exposed to different levels of humidity, clearly shows that the embedded force increases as the humidity increases. An increase in air humidity resulted in an increased water content in the wood leading to wood swelling and changes in dimensions. This is why the embedded force values of the absolutely dry samples were much lower than those of other samples (the average embedded force for heartwood samples was $1900.73 \mathrm{~N}$; the average embedded force for sapwood samples was $1920.36 \mathrm{~N}$ ). The samples exposed to sodium chloride salts exhibited the highest embedded force values (the average of $3049.33 \mathrm{~N}$ ). The samples with water content above $13.05 \%$ exhibited the best embedded force values.

\section{CONCLUSIONS}

\section{ZAKLJUČAK}

Significant influence of moisture content on the embedded force or the strength of beech dowels welded in the Scots pine bases (specimens) was determined. There was a statistically significant increase in the embedded force between the oven dry specimens and specimens conditioned to average moisture content of $8.87 \%$. Embedded force slightly decreased for the samples conditioned to $10.05 \%$ moisture content, and slightly increased for the samples conditioned to 13.05 $\%$ moisture content, but only for heartwood specimens, although these changes in embedded force were not statistically significant. Embedded forces for sapwood samples conditioned to $10.05 \%$ and $13.7 \%$ were almost the same.

Based on the obtained results, the moisture content of wood in the interval between 9 and $13 \%$ does not have statistically significant effect on the embedded force and this moisture content of wood is optimal for dowel rotary welding. In the future research, the observed moisture content intervals should be expanded to determine at which water content embedded force decreases significantly.

Oven dry samples had the smallest embedded forces, due to increased brittleness of wood. Dowels welded in heartwood and sapwood did not show statistically significant difference in embedded force.

\section{REFERENCES}

\section{LITERATURA}

1. Bocquet, J. F.; Pizzi, A.; Resch, L., 2007: Full-scale industrial wood floor assembly and structures by welded- through dowels. Holz als Roh- und Werkstoff, 65: 149155. https://doi.org/10.1007/s00107-006-0170-4.

2. Ganne-Chedeville, C.; Properzi, M.; Leban, J. M.; Pichelin, F., 2006: Parameters of wood welding: A study with infrared thermography. Holzforschung, 60: 434438. https://doi.org/10.1515/HF.2006.068.

3. Gfeller, B.; Pizzi, A.; Zanetti, M.; Pichelin, F.; Lehmann, M.; Delmotte, L., 2004: Solid wood joints by in situ welding of structural wood constituents. Holzforschung, 58 (1): 45-53. https://doi.org/10.1515/HF.2004.007.

4. Gfeller, B.; Zanetti, M.; Properzi, M.; Pizzi, A.; Pichelin, F.; Lehmann, M.; Delmotte, L., 2003: Wood bonding by vibrational welding. Journal of Adhesion Science and Technology, 17 (11): 1573-1589. https://doi.org/10.1163/156856103769207419.

5. Kanazawa, F.; Pazzi, A.; Kanazawa, M.; Delmotte, L.; Pichelin, F., 2005: Parameters influencing wood-dowel welding by high-speed rotation. Journal of Adhesion Science and Technology, 19 (12): 1025-1038. https://doi.org/10.1163/156856105774382444.

6. Leban, J. M.; Mansouri, H. R.; Omrani, P.; Pizzi, A., 2008: Dependence of dowel welding on rotation rate. Holz als Roh- und Werkstoff, 66: 241-242. https://doi.org/10.1007/s00107-008-0228-6.

7. Omrani, P.; Mansouri, H. R.; Pizzi, A., 2009: Linear welding of grooved wood surfaces. European Journal of Wood and Wood Products, 67 (4): 479-481. https://doi.org/10.1007/s00107-009-0334-0.

8. Omrani, P.; Masson, E.; Pizzi, A.; Mansouri, H. R., 2008: Emission of gases and degradation volatiles from polymeric wood constituents in friction welding of wood dowels. Polymer Degradation and Stability, 93: 794-799. https://doi.org/10.1016/j.polymdegradstab.2008.01.017.

9. Pizzi. A.; Leban, J. M.; Kanazawa, F.; Properzi, M.; Pichelin, F., 2004: Wood dowel bonding by high - speed rotation welding. Journal of Adhesion Science and Technology, 18 (11): 1263-1278.

https://doi.org/10.1163/1568561041588192.

10. Pizzi, A.; Properzi, M.; Leban, J. M.; Pichelin, F., 2003: Mechanically - induced wood welding. Maderas. Ciencia y technologia, 5 (2): 101-106. http://dx.doi.org/10.4067/S0718-221X2003000200001.

11. Pizzi, A.; Despres, A.; Mansouri, H. R.; Leban, J. M.; Rigolet, S., 2006: Wood joints by through-dowel rotation welding: microstructure, $13 \mathrm{C}$-NHR and water resistante. Journal of Adhesion Science and Technology, 20 (5): 427-436. https://doi.org/10.1163/156856106777144327.

12. Jones, D.; Pizzi, A., 2007: Frictional welding of dowels into modified wood. In: Proceedings of the $5^{\text {th }}$ COST E34, Bonding of Modified Wood., University of Ljubljana, Biotechnical Faculty, Bled-Slovenia, September $6^{\text {th }}$ 2007, pp. 13-19.

13. Resch, L.; Despres, A.; Pizzi, A.; Bocquet, J. F.; Leban, J. M., 2006: Welding-through doweling of wood panels. Holz als Roh- und Werkstoff, 64: 423-425. https://doi.org/10.1007/s00107-005-0090-8.

14. Stamm, B.; Natterer, J.; Navi, P. 2005: Joining of wood layers by friction welding. J Adhesion Sci. Technol., 19 (13-14): 1129-1139. https://doi.org/10.1163/156856105774429046.

15. Župčić, I.; Mihulja, G.; Bogner, A.; Govorčin, S.; Grbac, I., 2009: Zavarivanje termički modificirane grabovine. Drvna industrija, 60 (3): 161-166. https://doi.org/10.5552/drind.2011.1034.

16. Župčić, I.; Mihulja, G.; Bogner, A.; Grbac, I., 2011: Vrijeme trajanja zavarivanja kao važan čimbenik zavarivanja bukovine. Drvna industrija, 62 (2): 115-121. https://doi.org/10.5552/drind.2011.1041. 
17. Župčić, I., 2010: Čimbenici koji utječu na spajanje tokarenih bukovih elemenata tehnikom zavarivanja: Dissertation. University of Zagreb, Faculty of Forestry.

18. Župčić, I.; Vlaović, Z.; Domljan, D.; Grbac, I., 2014: Influence of Various wood species and cross-sections on strength of a dowel welding joint. Drvna industrija, 65 (2): 121-127.

https://doi.org/10.5552/drind.2014.1324.

19. ***HRN ISO 13061-1:2015 Fizikalna i mehanička svojstva drva - Metode ispitivanja za manje uzorke masivnog drva, 1. dio: Određivanje sadržaja vode za provođenje ispitivanja fizikalnih i mehaničkih svojstava.

20. ***HRN ISO 13061-2:2015 Fizikalna i mehanička svojstva drva - Metode ispitivanja za manje uzorke ma- sivnog drva, 2. dio: Određivanje gustoće za provođenje ispitivanja fizikalnih i mehaničkih svojstava.

\section{Corresponding address:}

IVAN ŽULJ, BSc

University of Zagreb

Faculty of Forestry

Svetošimunska 25, p.p. 422

HR-10002 Zagreb, CROATIA

e-mail: izulj@sumfak.hr 